\title{
Eastern oyster, Crassostrea virginica, valve gape behavior under diel-cycling hypoxia
}

\author{
Elka T. Porter ${ }^{1}\left[\right.$ · Denise L. Breitburg ${ }^{2}$
}

Received: 28 March 2016 / Accepted: 30 August 2016

(C) Springer-Verlag Berlin Heidelberg 2016

\begin{abstract}
Hypoxia and anoxia in many estuaries worldwide can cause a wide range of negative effects on animals that are directly exposed or indirectly influenced by food web interactions. Typically, experimental studies focus on animal behavior as a function of continuous exposure to low dissolved oxygen (DO) conditions rather than short-term fluctuations. Dissolved oxygen concentrations [DO] can, however, vary throughout the day, and water can become hypoxic for minutes to hours, often during the late night/early morning hours in the summer. Valve gape of 1-year-old eastern oysters, Crassostrea virginica, from Maryland, USA, was continuously measured while exposed to diel-cycling DO in aquaria during normoxic, hypoxic, and supersaturated phases of the cycle over several 2-day periods (July-August 2012). Severe hypoxia $\left(0.6 \mathrm{mg} \mathrm{DO} \mathrm{L}^{-1}\right)$ induced oysters to close for significantly longer times than normoxic $\left(7.3 \mathrm{mg} \mathrm{DO} \mathrm{L}^{-1}\right)$ conditions. Oysters exposed to mild hypoxia $\left(1.7 \mathrm{mg} \mathrm{DO} \mathrm{\textrm {L } ^ { - 1 } )}\right.$ closed for a similar amount of time as oysters held at normoxia and severe hypoxia. At severe hypoxia, more than one-third of the oysters closed simultaneously and closed
\end{abstract}

Responsible Editor: J. Grassle.

Reviewed by Undiclosed experts.

Electronic supplementary material The online version of this article (doi:10.1007/s00227-016-2980-1) contains supplementary material, which is available to authorized users.

Elka T. Porter

eporter@ubalt.edu

1 Yale Gordon College of Arts and Sciences, University of Baltimore, 1420 N. Charles St., Baltimore, MD 21201, USA

2 Smithsonian Institution, 664 Contees Wharf Road, Edgewater, MD 21037, USA immediately when they encountered severe hypoxia while oysters at mild hypoxia often closed later in the low oxygen phase of the cycles. When normoxia was reintroduced after severe hypoxia, most oysters opened immediately and gaped throughout the period. The results indicate that while 1-yearold oysters responded negatively to diel-cycling low [DO], especially to severe hypoxia, they rapidly opened during the normoxic period that followed, potentially reducing any negative effects of a fluctuating environment.

\section{Introduction}

Hypoxia, i.e., dissolved oxygen concentrations [DO] sufficiently low to negatively affect biological and ecological processes but often functionally defined as [DO] of $<2 \mathrm{mg}$ DO L ${ }^{-1}$ (Vaquer-Sunyer and Duarte 2008), and anoxia (functionally defined as [DO] of $0.2-$

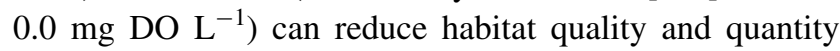
for macrofauna in the world's estuaries, coastal waters, and deep ocean (Diaz and Rosenberg 2008; Levin and Breitburg 2015). The frequency and intensity of anoxic and hypoxic events in estuaries are increasing worldwide as a result of anthropogenic nutrient loads (Diaz and Rosenberg 1995; Patterson et al. 2014) and are predicted to increase even further due to global climate change (Altieri and Gedan 2015). Seasonally persistent hypoxic zones are yearly occurrences in many stratified, nutrient-enriched estuaries such as the Chesapeake Bay, USA (Diaz and Rosenberg 2008). In addition, diel-cycling hypoxia is common in shallow waters, in both the Chesapeake and elsewhere (Tyler et al. 2009; Breitburg et al. 2015).

Many studies have examined the tolerance of benthic macrofauna to hypoxia and anoxia (e.g., Stickle et al. 1989; Gamenick et al. 1996; Modig and Olafsson 1998; Riedel 
et al. 2012; Lombardi et al. 2013; Jansson et al. 2015), as well as effects on a large scale such as shifts in species distributions, abundances, and composition (Diaz and Rosenberg 1995; Gooday et al. 2009). For example, on the Louisiana-Texas Shelf, the ecosystem has shifted to a younger, smaller-sized, short-lived fauna (Diaz and Rosenberg 1995). These types of shifts sometimes occur after mass mortality of species that are sensitive to hypoxia and anoxia (Montagna and Ritter 2006).

Behavioral changes typically precede community collapse (Villnäs et al. 2012), and various responses of organisms to hypoxia and anoxia have been observed. Mobile organisms such as fish respond to low DO conditions by moving from low DO regions to water with higher [DO] (Breitburg 2002; Costantini et al. 2008; Ludsin et al. 2009; Zhang et al. 2009), hypoxia effectively reducing the available habitat. However, sessile invertebrates and organisms with limited mobility are unable to avoid low DO by large-scale movement. Behavioral responses include hyper-extended bivalve siphons (Sparks and Strayer 1998), abandonment of tubes and burrows (Diaz and Rosenberg 1995; Montagna and Ritter 2006), movements to the sediment surface (Llansó 1992; Montagna and Ritter 2006), increased vertical and horizontal movements (Riedel et al. 2008), and reduced burrowing depths (Villnäs et al. 2012). Riedel et al. (2014) experimentally induced hypoxia and observed behavioral changes in macroinvertebrates until their death and found that macroinvertebrate behavioral responses altered community structure and the ecosystem processes.

Increasing attention has focused on diel cycling of DO. The $[\mathrm{DO}]$ in shallow estuarine waters varies over the course of a day (Breitburg 1990; Montagna and Ritter 2006) and can dip to hypoxic levels at the end of the night or in the early morning during the summer when low solar insolation results in little or no oxygen-producing photosynthesis to compensate for oxygen-consuming aerobic respiration (Montagna and Ritter 2006; Tyler et al. 2009). Baumann et al. (2015) also found that the tides affected the diel cycling of low DO conditions with the most extreme minima observed when low tides coincided with the end of the night. Water can remain hypoxic for hours before [DO] increases again to normoxic conditions (Montagna and Ritter 2006; Tyler et al. 2009; Breitburg et al. 2015).

It is not clear how sessile invertebrates such as the Eastern oyster Crassostrea virginica respond behaviorally to the short phases (on the order of hours) of low DO conditions that are frequent in estuaries (Tyler et al. 2009; Breitburg et al. 2015), and the normoxic periods that follow. Laboratory experiments and field deployments have indicated that diel-cycling hypoxia can increase the prevalence and intensity of Perkinsus marinus infections in $C$. virginica and reduce growth rates (Clark 2014; Breitburg et al. 2015; Keppel et al. 2015). However, behavioral compensation such as increased gape and reduced valve closure could reduce the food web or the ecosystem effects of diel-cycling hypoxia by minimizing the effects on oysters themselves and on the phytoplankton they consume. While $C$. virginica in the northeast USA often occur in shallow subtidal reefs, in the southeast they are usually intertidal (Dame and Patten 1981) and thus accustomed to periods of emersion, which can result in internal hypoxia and relatively high temperatures in the summer.

Monitoring valve gape behavior, i.e., the opening and closing of valves, is one way of assessing bivalve responses to environmental conditions. Valve closure has been used as an indicator of adverse conditions such as the presence of contaminants (de Zwart et al. 1995; Kádár et al. 2001; Soliman et al. 2015), toxic algae (Shumway and Cucci 1987; Basti et al. 2009; Tran et al. 2010), thermal pollution (Shumway and Koehn 1982; Nicastro et al. 2012; Dowd and Somero 2013), food quantity (Higgins 1980; Riisgård et al. 2006; Robson et al. 2010a), feeding regime (Riisgård et al. 2006; Robson et al. 2010b), emersion (Nicastro et al. 2010; Dowd and Somero 2013), photoperiod (Loosanoff and Nomejko 1946; Comeau et al. 2012), pH (Pynönnen and Huebner 1995; Jakubowska and NormantSaremba 2015), and combined $\mathrm{pH}$ and dissolved oxygen (Jakubowska and Normant 2015). A previous study using valve gape responses to DO in oysters, specifically Crassostrea virginica, examined responses only to continuous, rather than cycling, exposures to hypoxia (Lombardi et al. 2013).

We continuously measured the gape response to [DO] of eastern oysters exposed to the diel cycling of DO. We note that valve gape during diel-cycling hypoxia has not previously been measured on any species. We tested four hypotheses: (1) Oysters close in response to cyclically induced mild hypoxia $\left(1.7 \mathrm{mg} \mathrm{DO} \mathrm{L}^{-1}\right)$ and oysters are closed even longer if hypoxia is more severe $\left(0.6 \mathrm{mg} \mathrm{DO} \mathrm{L}^{-1}\right)$, and (2) more oysters close simultaneously in response to mild and severe hypoxia during diel-cycling hypoxia than when DO remains near $100 \%$ saturation (normoxia). To determine the short-term responses of oysters to the cessation of hypoxia, we tested the hypotheses that: (3) more oysters are open in the normoxic part of the cycle after hypoxia than in the control treatment with continuous $100 \%$ DO saturation to compensate for the time being closed during hypoxia, and (4) oysters open rapidly after a hypoxic event, perhaps as an adaptation to a rapidly fluctuating environment.

\section{Materials and methods}

Gape responses for 36-65 mm long, 1-year-old oysters, Crassostrea virginica (purchased from Marinetics, 


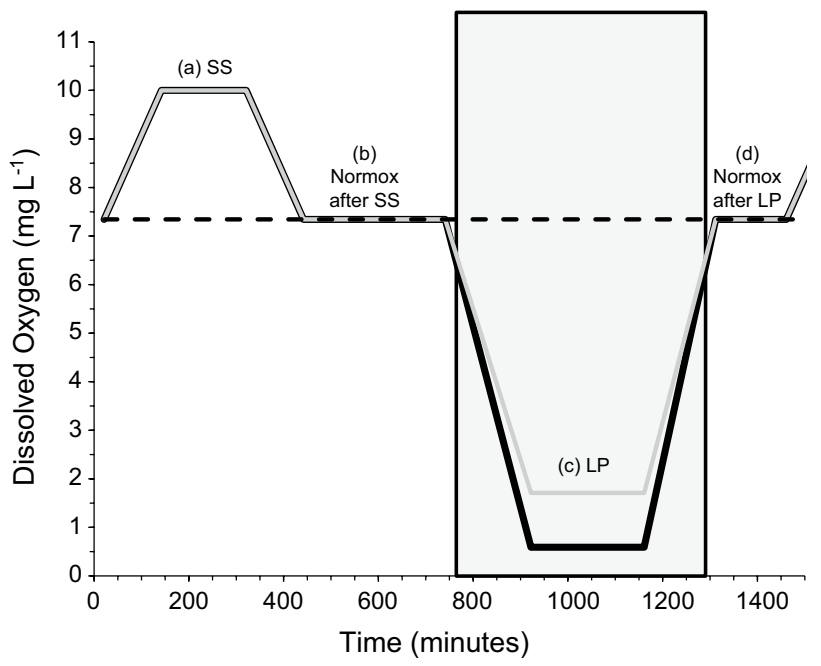

Fig. 1 Example of daily experimental manipulation of [DO] to induce diel-cycling hypoxia (modified from Burrell et al. 2015). $a$ supersaturation (SS), $b$ normoxia after supersaturation (Normox after SS), $c$ low plateau (LP), $d$ normoxia after low plateau (Normox after LP). Low plateau varied among three different treatments: thick line, severe hypoxia $\left([\mathrm{DO}]=0.6 \mathrm{mg} \mathrm{L}^{-1}\right)$, thin line, mildly hypoxic $\left([\mathrm{DO}]=1.7 \mathrm{mg} \mathrm{L}^{-1}\right)$, dashed line, normoxia $\left([\mathrm{DO}]=7.3 \mathrm{mg} \mathrm{L}^{-1}\right)$. Shaded box indicates 10 -h dark period

Cambridge, Maryland), were measured 2 days week ${ }^{-1}$ over a 6-week period during July-August 2012 at the Smithsonian Environmental Research Center, Maryland. Oysters were held in $75-\mathrm{L}$ aquaria and exposed to cyclical changes in [DO] mimicking diel-cycling hypoxia as found in nature (Tyler et al. 2009; Breitburg et al. 2015). Oysters were acclimated in aquaria June 30-July 4, 2012. DO cycles (see below) were started July 5, 2012, and gape experiments took place from July 16-August 22, 2012. Oysters were held under a 14-h light:10-h dark photoperiod, 7 days per week (Keppel et al. 2015). Disease prevalence was low and similar in all treatments (Keppel et al. 2015) during the gape experiments.

Supersaturation, normoxia after supersaturation, low DO (low plateau) conditions (or normoxia in the case of controls), and normoxia after the "low plateau" were run consecutively (Fig. 1). For the severely and mildly hypoxic diel cycles, values were taken to supersaturated DO values over $2 \mathrm{~h}$ (up-to-supersat), held at high values for $2 \mathrm{~h}$ (supersaturation plateau), brought back to normoxia over $2 \mathrm{~h}$ (down-to-normoxia) and held at normoxia for $6 \mathrm{~h}$. [DO] was decreased over $3 \mathrm{~h}$ (ramp down), held at continuous low values for $4 \mathrm{~h}$ (low plateau), brought back to normoxia over $3 \mathrm{~h}$ (ramp up), held for $2 \mathrm{~h}$ (normoxia), and taken to supersaturated DO values (Fig. 1; Keppel et al. 2015). The low plateau phase and the phases ramping up or down to it $(10 \mathrm{~h})$ were imposed in the dark to simulate nightly hypoxia; otherwise, light levels simulated those at a 2-m depth in the Rhode River, Maryland, on a sunny day (Keppel et al. 2015). [DO] was manipulated in each aquarium (Fig. 1).

The experimental system included flowing, raw estuarine water in which the [DO] was controlled by manipulating the ratio of air, nitrogen and oxygen gases delivered to the aquaria; details of the diel-cycling setup and system performance can be found in Burrell et al. (2015). Food was added to ambient estuarine water in our experiments to minimize any food limitation. Oxyguard Standard DO model III probes (Oxyguard International A/S, Birkeroed, Denmark) measured the [DO], Durafet III probes (Honeywell International, Morristown, New Jersey, USA) measured the $\mathrm{pH}$, and the system was controlled by LabVIEW software (National Instruments).

Nightly hypoxia was mimicked by reducing DO conditions over a 3-h period, after which [DO] was held stable at $0.6 \mathrm{mg} \mathrm{DO} \mathrm{L}^{-1}$ (severe hypoxia treatment), $1.7 \mathrm{mg} \mathrm{DO} \mathrm{L}^{-1}$ (mild hypoxia treatment), or holding the oysters at $7.3 \mathrm{mg} \mathrm{DO} \mathrm{L} \mathrm{L}^{-1}$ (normoxia: control treatment) during the low plateau phase of the cycle for $4 \mathrm{~h}$ (Fig. 1). Next, aquaria were returned to normoxic levels, followed by a supersaturation phase and another normoxic phase. The $\mathrm{pH}$ was also cycled through the controlled addition of $\mathrm{CO}_{2}$ and $\mathrm{CO}_{2}$-stripped air. However, the percent time oysters were closed was similar under cyclical $(\mathrm{pH}=7.8-7.0)$ and control $(\mathrm{pH}=7.8) \mathrm{pH}$ treatments (nested ANOVA, LSmeans comparisons) for the normoxia after the low $\left(F_{3,13} 0.81\right.$, $P=0.6628)$, low plateau $\left(F_{3,13} 3.26, P=0.4309\right)$, normoxia after supersaturation $\left(F_{3,13} 0.06, P=0.6677\right)$, and supersaturation $\left(F_{3,13} 0.80, P=0.0582\right)$ phases. Thus, all data (electronic supplement) for the severe hypoxia treatment were pooled.

Alkalinity ranged from 1450 to 1760 over the course of the experiment, salinity ranged from 10 to 14 , and temperature ranged from 22 to $30^{\circ} \mathrm{C}$. Values of all three parameters were similar to ambient conditions near the seawater intake. Gape duration, frequency, and duration of valve closure changed dramatically as water temperatures approached and exceeded the normal environmental conditions for the freshwater bivalves Anodonta cygnea and Margaritifera falcata (Rodland et al. 2009); however, oysters were well within their normal range in shallow water during summer in Chesapeake Bay and elsewhere. Moreover, for each weekly gape experiment, $C$. virginica from all treatments were used. Cycling was maintained 5 days week $^{-1}$ alternated with no cycling in all treatments for 2 days week $^{-1}$ to increase realism for systems like Chesapeake Bay in which diel-cycling hypoxia is frequently interrupted by winds (Breitburg et al. 2015). In addition, when groups of 30-100 oysters were tested together, total filtration rates were reduced while [DO] was low, but sometimes increased above those of oysters held under continuous high oxygen 
Fig. 2 a Bivalve gape sensor with close-up of strain gauge element, $\mathbf{b}$ side view of gape sensor attached to oyster showing loop of sensor. Photographs by Porter (a)

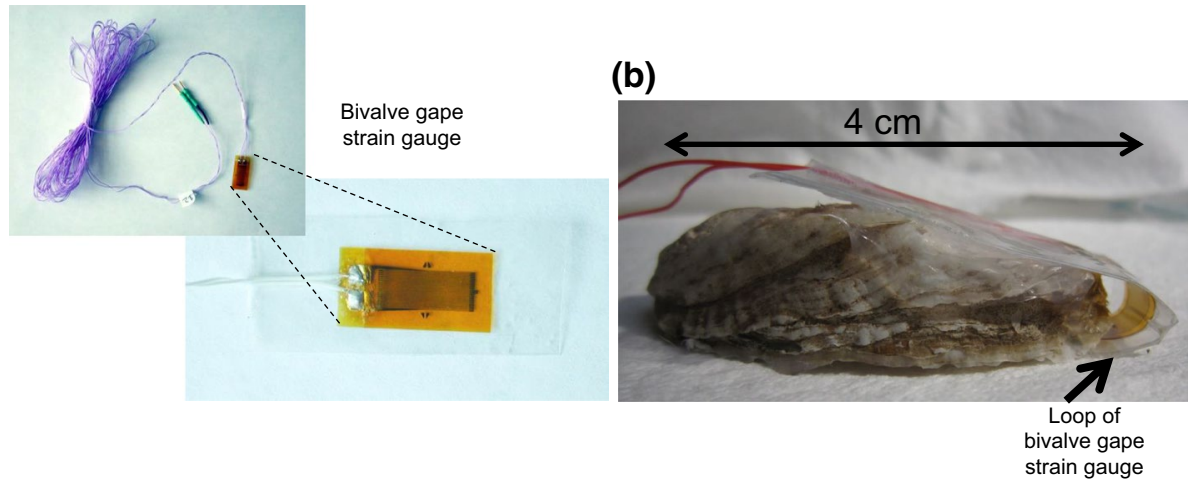

concentrations when conditions returned to normoxia (Clark 2014; Breitburg et al. 2015). However, the behavioral mechanisms underlying the temporal variation in clearance rates observed at the population level through the high and low oxygen phases of diel cycles were not previously known.

\section{Gape measurements}

We performed valve gape trial runs with 12 oysters in August 2011, and then, a full gape experiment from July 16-August 22, 2012 in tanks described in Keppel et al. (2015). The periods analyzed for valve closure were hypoxia (normoxia for controls) plateau phase, normoxia plateau phase after hypoxia, supersaturation plateau phase (normoxia for controls), and normoxia plateau phase after supersaturation (Fig. 1). For the severe hypoxia treatment with cyclical $\mathrm{pH}(\mathrm{pH}=7.8-7.0)$, we had four tanks with 3, 3,3 , and 4 oysters with sensors per tank $(n=13$, electronic supplement). For the severe hypoxia treatment with control $\mathrm{pH}(\mathrm{pH}=7.8$ ), we had four tanks with $3,3,2$, and 3 oysters with sensors per tank; a fifth tank with just one oyster with a sensor was excluded from the analysis $(n=11$, electronic supplement). For the mild hypoxia treatment, we had four tanks with 2, 2, 4, and 3 oysters with sensors per tank ( $n=11$, electronic supplement). For the control treatment, we had four tanks with $3,3,3$, and 2 oysters with sensors per tank ( $n=11$, electronic supplement). Different oysters were used for each measurement. The overall sample size in each aquarium was affected by occasional sensor failure as well as equipment limitations in deploying sensors in the facility. However, we continuously tested 46 oysters, 36-65 mm long, for 2 days week $^{-1}$ over a period of 6 weeks (except week 4, when other experiments were performed). No effect of time (different weeks) was found, and measurements over different weeks were treated as replicates.

For each weekly run, oysters were removed from their aquaria (electronic supplement) before the low plateau period. Oysters were numbered with nail polish, the shells dried, and sealed strain gauges (SG13/1000-LY43 or LY41, Omega Engineering Inc., Stanford, Connecticut) glued onto the shells with aquarium sealant (Fig. 2). Strain gauges have been used in the past to measure valve gape (e.g., Higgins 1980; Shumway and Cucci 1987), but were attached by a tether instead of directly to the oysters. We only removed oysters from the aquaria to equip them with sensors, after which we placed them in buckets with ambient flow-through oxygenated water and reintroduced them to their aquaria during the normoxia period after the low plateau; logging of valve gape started during the phase leading up to supersaturation (Fig. 1). Strain gauge voltage is linearly related to the degree of oyster gape (unpublished data); however, the relationship varies from sensor to sensor and calibration is time consuming. It was also noted that oysters often open very wide very quickly. To minimize the time that oysters were not in their aquaria, the relationship was not assessed here and just open versus closed was defined for each sensor-equipped oyster. During the experiment, a Campbell CR10X data logger captured readings every $2.5 \mathrm{~s}$ and averaged readings every $15 \mathrm{~s}$. Thus, there were four logged readings $\mathrm{min}^{-1}$ and each reading was the average of six data points. With very few exceptions, oysters gaped virtually immediately after reintroduction to the aquaria allowing us to assess the signal generated by a gaping oyster before exposing them to hypoxia. Oysters were not affected by wearing the sensors (unpublished data), and C. virginica gape behavior under normoxia was similar to C. virginica gape behavior found in previous studies (e.g., Loosanoff and Nomejko 1946; Higgins 1980).

Before the oysters were removed at the end of a run, they were triggered to close to determine the magnitude and the direction of the closing signal. Data were linearized for linear drift (Fig. 3) in signal voltage, and an oyster was operationally defined as open when the sensor reading was more than half its maximum open voltage. The percentage of oysters that were more or less closed (operationally defined as a sensor reading less than half of its maximum open voltage), as a function of time was determined and 
Fig. 3 Example of how the gape data were linearized. A 2D time series of gape data in a treatment with severe hypoxia $\left([\mathrm{DO}]=0.6 \mathrm{mg} \mathrm{L}^{-1}\right)$ during the hypoxic phase. a Dark-light cycle, $\mathbf{b}$ [DO] with periods of hypoxia. c The gape monitor included linear drift in the data due to sensor corrosion which was $\mathbf{d}$ removed in post-processing. For interpretation of open and closed segments see text. At the end of a run, oyster was triggered to close to determine magnitude and direction of closing spike. Magnitudes between different sensors are not comparable

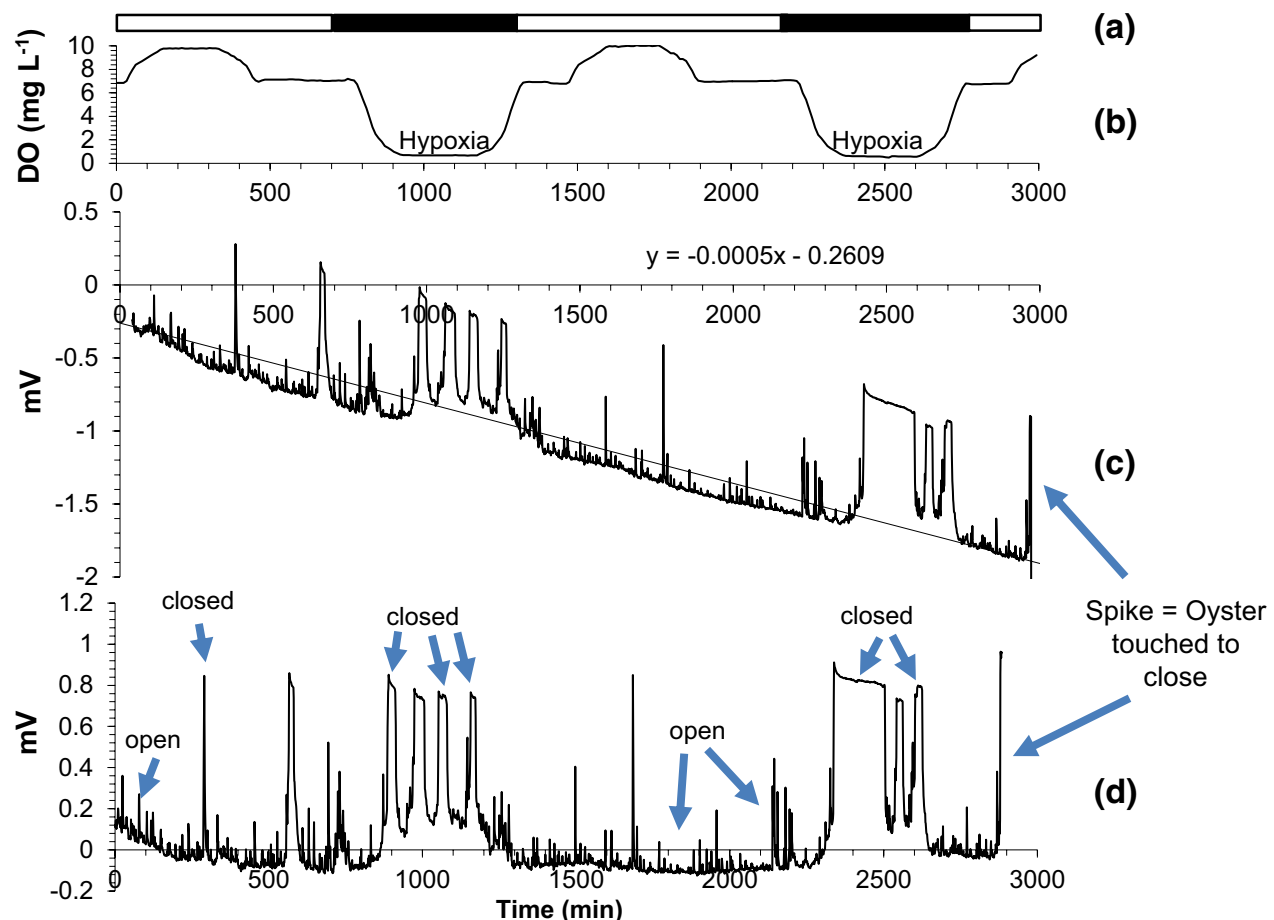

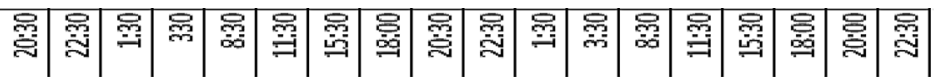

Approximate real time (hrs)

the fractional time was recorded when more than one-third of the oysters with sensors were closed in each treatment. Oysters typically opened wide quickly and did not spend much time at intermediate values.

Statistical analyses tested for the effect of [DO] treatment on the percent of time oysters were closed during each plateau phase of the cycle using a nested ANOVA (oysters nested within tanks) in SAS (SAS 9.4). There were three DO treatments, four (eight for severe hypoxia) tanks per treatment, and 2-4 oysters per tank (for sample sizes see electronic appendix).

\section{Results}

Oysters exposed to continuously normoxic estuarine water (i.e., no hypoxia during the low plateau phase of the daily cycle, $n=11$ ) were open most of the time, with variation among individuals in the temporal pattern of closures (e.g., Figure 4), and no difference between light and dark periods. In contrast, most oysters exposed to periodic cycles of severe hypoxia $\left(0.6 \mathrm{mg} \mathrm{DO} \mathrm{L}^{-1}, n=24\right.$, cyclical and control $\mathrm{pH}$ combined) closed soon after the target [DO] was reached and remained closed for most of the time that severe hypoxia persisted (Fig. 5). With mild (1.7 mg DO L ${ }^{-1}, n=11$ ) hypoxia, closings often occurred later during the low plateau phase instead of at the point when target [DO] was reached (Fig. 6). Analyzing the different phases with a nested ANOVA, we found statistically significant differences between treatments in the low plateau phase (ANOVA, $F(2,14)=5.05, P=0.0224$, Fig. 7a). However, we found no significant differences between treatments in the normoxia after low plateau phase (ANOVA, $F(2,14)=1.22, P=0.3249$, Fig. $7 b$ ), the supersaturation phase (ANOVA, $F(2,14)=0.26, P=0.7748$, Fig. 7c), or the normoxia after the supersaturation phase (ANOVA, $F(2,14)=0.01, P=0.9914$, Fig. 7d). Thus, we performed pairwise comparisons of the treatments in the low plateau phase and found that while oysters in the severely and mildly hypoxic phases were closed a similar amount of time $(P=0.16$, Fig. $7 \mathrm{a})$ and oysters in the mildly hypoxic and control were closed a similar amount of time $(P=0.26$, Fig. $7 \mathrm{a})$, oysters were closed significantly longer in severe hypoxia $(40.3 \pm 5.7 \%$ of the time closed) than in the control treatment $(4.5 \pm 1.7 \%$ of the time $)$ $(P=0.001$, Fig. 7a).

In addition, in the low plateau phase, up to $75 \%$ of the oysters closed simultaneously during severe hypoxia compared to about $50 \%$ during mild hypoxia (Fig. 8a, b) and $33 \%$ in the control group (Fig. 8c). Using a threshold of $1 / 3$ of the oysters closed for potential warning purposes, more than one-third of the control treatment oysters were 

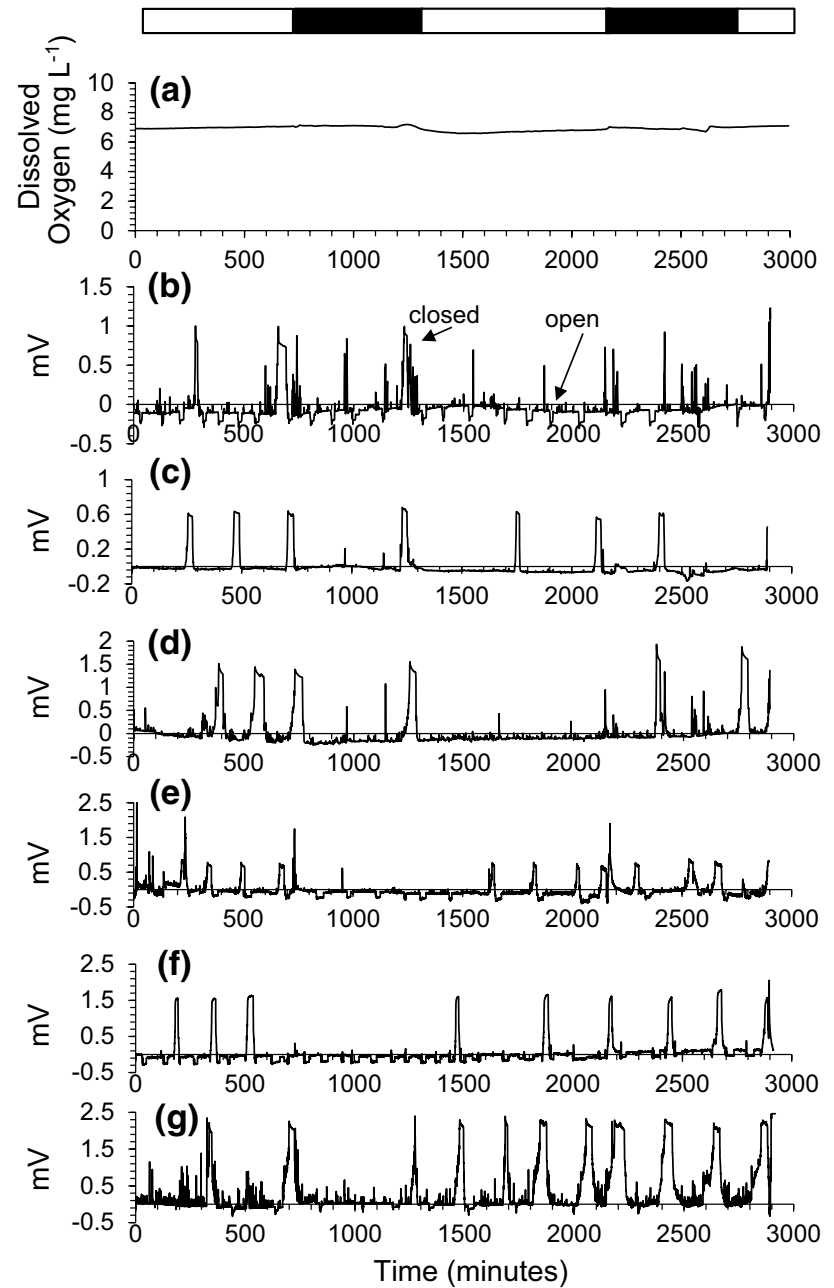

Fig. 4 a Measured [DO] $\left(7.3 \mathrm{mg}\right.$ DO L $\left.{ }^{-1}\right)$ over a 2D time period in control treatment (normoxia throughout). b-g Time series of oyster gape responses over two days of monitoring with a diel-cycling pattern of [DO] in a. Subset of six gape sensors per treatment to illustrate details of the traces of different oysters and compare to actual [DO] in a. Black bars represent time experiment was kept in the dark to mimic night time and white bars light, i.e., day time

closed for only $3 \%$ of the time in the low plateau phase (Table 1, Fig. 8c). In contrast, under severe hypoxic conditions in the low plateau phase, more than a third of the oysters were closed for $51 \%$ of the time (Table 1; Fig. 8a), and in the mildly hypoxic treatment more than one-third of the oysters were closed for $29 \%$ of the time (Table 1; Fig. 8b).

During the normoxic period that followed the severe hypoxic low plateau period, most oysters from all treatments gaped (Figs. 7b, 4b, 8a, b, c). Oysters exposed to severe hypoxia during the low plateau phase opened up very soon after the DO levels began rising, considerably before normoxia was reached (Fig. 5). More than one-third of the oysters from all treatments were closed for only zero (severe hypoxia) to five percent of the time (mild hypoxia) during the normoxia phase after supersaturation (Table 1). Oysters from
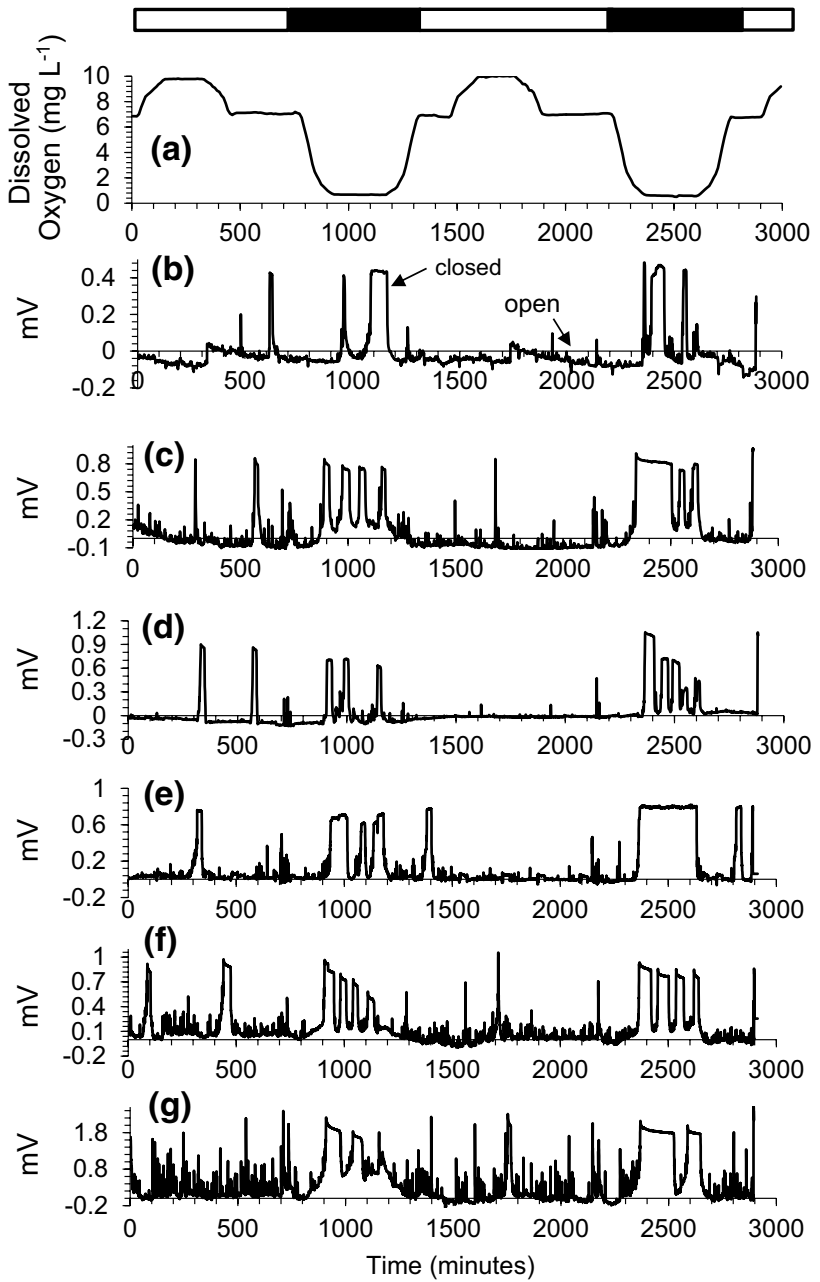

Fig. 5 a Measured [DO] over a 2D time period. Low plateau phase was held at $0.6 \mathrm{mg} \mathrm{DO} \mathrm{L}^{-1}$. b-g Time series of oyster gape responses over 2 days of monitoring with a diel-cycling pattern of [DO] in $\mathbf{a}$. Subset of six gape sensors per treatment to illustrate details of the traces of different oysters and compare to actual [DO] in a. Black bars represent time experiment was kept in the dark to mimic night time and white bars light, i.e., day time

all treatments remained open most of the time in the supersaturation and the normoxia period after the supersaturation phases (Figs. 5, 6, 7c, d, 8 a, b, c; Table 1). Oysters showed this pattern over consecutive diel cycles after the hypoxic periods (e.g., Figure 5). The difference in the opening rates of oysters (low plateau percent time closed minus normoxia after low plateau percent time closed) was about $40 \%$ and significantly higher (ANOVA, $F(2,14)=12.33, P=0.0008$ ) for severe hypoxia than mild hypoxia and the control (Fig. 9).

\section{Discussion}

Oysters with an ample supply of food responded quickly to fluctuating [DO] conditions due to diel-cycling hypoxia. 

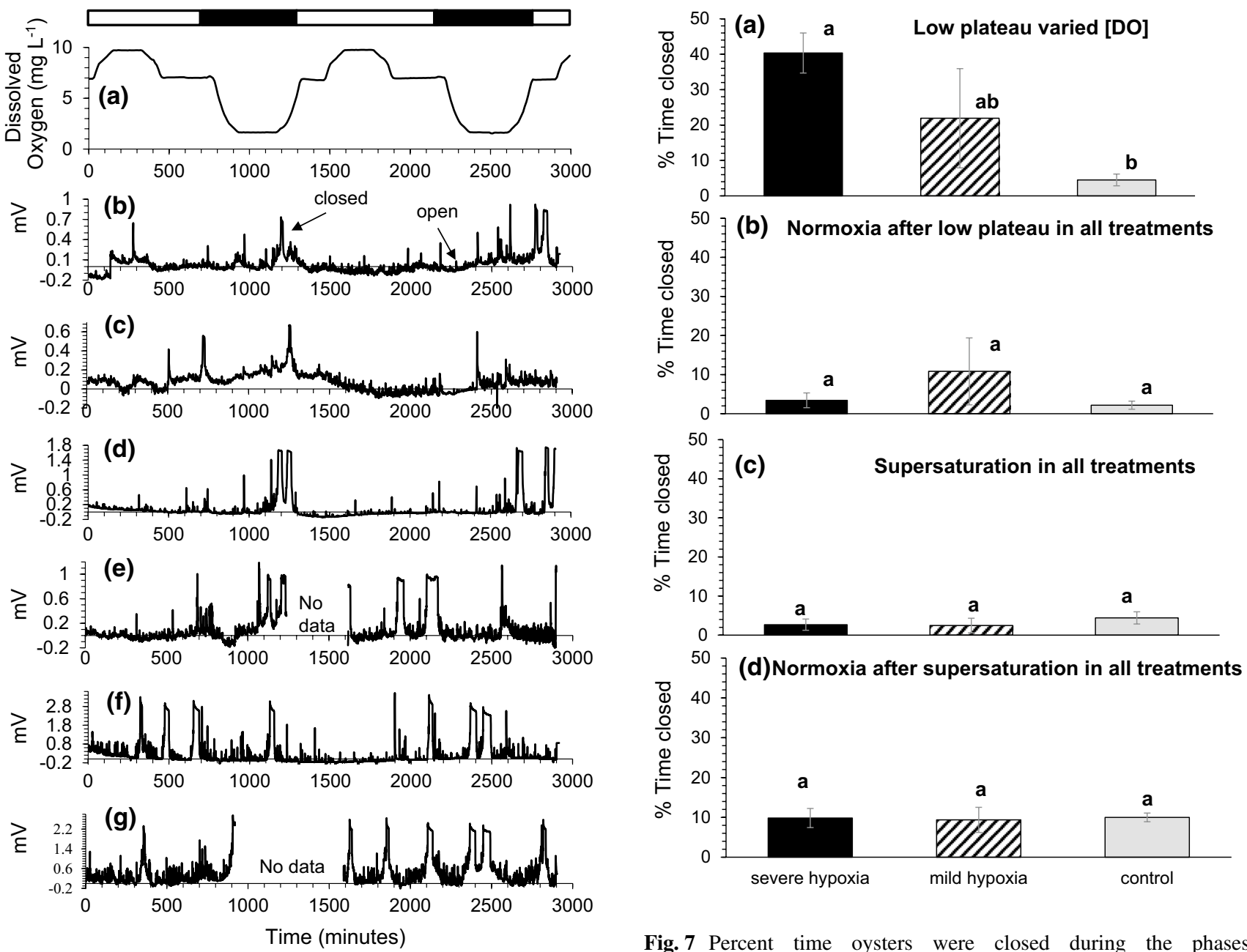

Fig. 6 a Measured [DO] over a 2D time period. Low plateau phase was held at $1.7 \mathrm{mg}$ DO L ${ }^{-1}$. $\mathbf{b}-\mathbf{g}$ Time series of oyster gape responses over 2 days of monitoring with a diel-cycling pattern of [DO] shown in a. Subset of six gape sensors per treatment to illustrate the details of the traces of different oysters and compare to actual [DO] in a. Black bars represent the time experiment was kept in the dark to mimic night time and white bars light, i.e., day time. Power was off for a period in $\mathbf{e}$ and $\mathbf{g}$ ("no data")

Oysters repeatedly closed during the hypoxic phases, especially the severe hypoxia $\left(0.6 \mathrm{mg}\right.$ DO L $\left.\mathrm{L}^{-1}\right)$, but often showed a delayed closing response in mild hypoxia (1.7 mg DO L $\left.{ }^{-1}\right)$. All oysters opened again when [DO] increased to normoxia. Oysters did not respond to the difference in dark and light conditions, and all oysters we tested survived the 4-h hypoxia exposures.

Behavioral changes are initial macrobenthic responses to decreasing [DO] (Villnäs et al. 2012; Riedel et al. 2014). As we predicted (hypothesis 1), oysters closed in response

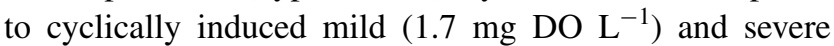
(0.6 mg DO L ${ }^{-1}$ ) hypoxia. Oysters also remained closed significantly longer in severe hypoxia $\left(0.6 \mathrm{mg} \mathrm{DO} \mathrm{\textrm {L } ^ { - 1 } )}\right.$ compared to the control. Thus, behavioral adjustments

Fig. 7 Percent time oysters were closed during the phases of the diel cycles (a-d). a Low plateau: [DO] during the low plateau: $0.6 \mathrm{mg}$ DO $\mathrm{L}^{-1}=$ severely hypoxic $(n=8)$, $1.7 \mathrm{mg} \mathrm{DO} \mathrm{L}{ }^{-1}=$ mildly hypoxic $(n=4), 7.3 \mathrm{mg} \mathrm{DO} \mathrm{L}^{-1}=$ control $(n=4)$. b Normoxia plateau after low, $\mathbf{c}$ supersaturation plateau, d normoxia plateau after supersaturation. Different letters above bars indicate statistical differences (nested ANOVA, $P \leq 0.05$ ). Error bars are standard errors of the mean. Data for severely hypoxic and control $\mathrm{pH}(\mathrm{pH}=7.8)$ and severely hypoxic and cyclical $\mathrm{pH}(\mathrm{pH}=7.8-7.0)$ were pooled, see text and electronic supplement

regulate the time of activity and avoid times of extreme conditions as suggested by Huey and Bennett (1990). Riedel et al. (2014) found that macroinvertebrate behavior influenced community structure and ecosystem processes. In this case, extended closing behavior could have negative consequences for community structure and the ecosystem. Shell gape responses by bivalves have previously been seen in experiments with more prolonged exposure to low DO than we tested. For example, shell activity and shell gape of the Pearl oyster increased exponentially over [DO] of 4 to $1 \mathrm{mg} \mathrm{DO} \mathrm{L}^{-1}$ (Dharmamaraj 1983). Lombardi et al. (2013) found that oysters continuously exposed to $0.5 \mathrm{mg} \mathrm{DO} \mathrm{L}{ }^{-1}$ were closed for $6 \mathrm{~h}$, but $20 \%$ gaped in 6-48 h, and 20-50\% gaped from $48 \mathrm{~h}$ to the end of the 
(a)

(b)
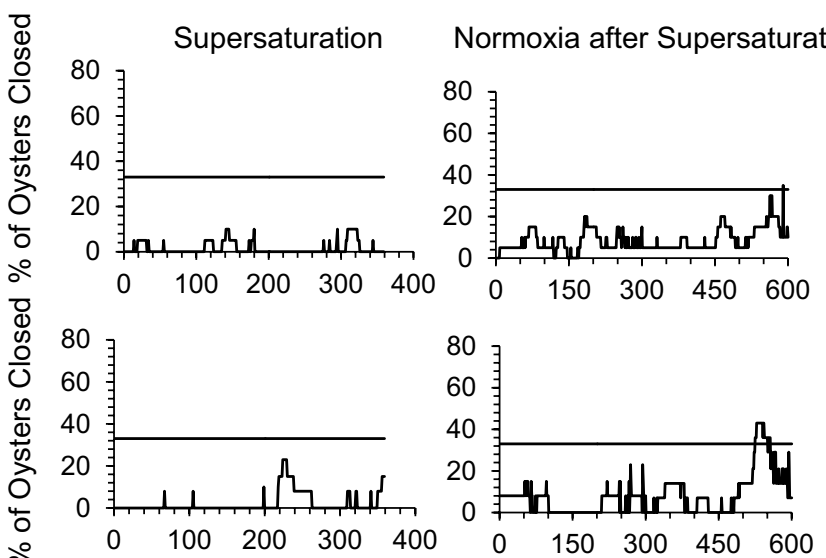

(c)
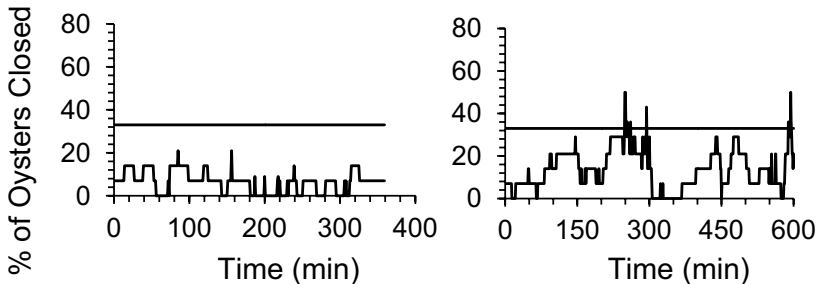

Fig. 8 a-c Percent of oysters simultaneously closed versus time over different phases in Figs. 1 and 7. Horizontal line indicates where one-third of oysters were closed; a treatment with severely hypoxic (0.6 mg DO L $\left.{ }^{-1}\right)$ conditions in the plateau phase, $\mathbf{b}$ treatment with

Table 1 Percent time (\% time) that more than one-third of the oysters were simultaneously closed during different oxygen phases over the diel cycle (see Figs. 1, 8)

\begin{tabular}{lllll}
\hline LP $\left(\mathrm{mg} \mathrm{DO} \mathrm{L}^{-1}\right)$ & $\begin{array}{l}\text { SS }(\% \\
\text { time) }\end{array}$ & $\begin{array}{l}\text { Normoxia } \\
\text { after SS (\% } \\
\text { time) }\end{array}$ & $\begin{array}{l}\text { LP }(\% \\
\text { time })\end{array}$ & $\begin{array}{l}\text { Normox } \\
\text { after } \\
\text { LP }(\% \\
\text { time })\end{array}$ \\
\hline 7.3 (control) & 0 & 2 & 3 & 0 \\
1.7 & 0 & 5 & 29 & 0 \\
0.6 & 0 & 0 & 51 & 0 \\
\hline
\end{tabular}

Zeros indicate the group is open

$L P$ low plateau, SS supersaturation, Normox normoxia

experiment. In contrast to these studies, our experiments provide information on gape behavior of oysters exposed to cycling conditions that typify shallow water habitat that oysters commonly inhabit.

In the present study, oysters did not respond to the light:dark photoperiod and the oysters in the control treatment (normoxia throughout, Fig. 1) were open $94 \%$ of the time at $22-30{ }^{\circ} \mathrm{C}$. These results are similar to those of Loosanoff and Nomejko (1946), who found that fed C. virginica did not respond to light and were open $94 \%$ of the time at $17-28{ }^{\circ} \mathrm{C}$. These authors did not measure [DO]. It also compares well to Higgins (1980) who found that fed oysters were open $94 \%$ of the time at $22{ }^{\circ} \mathrm{C}$. Comeau et al.
Low Plateau

Normoxia after Low Plateau
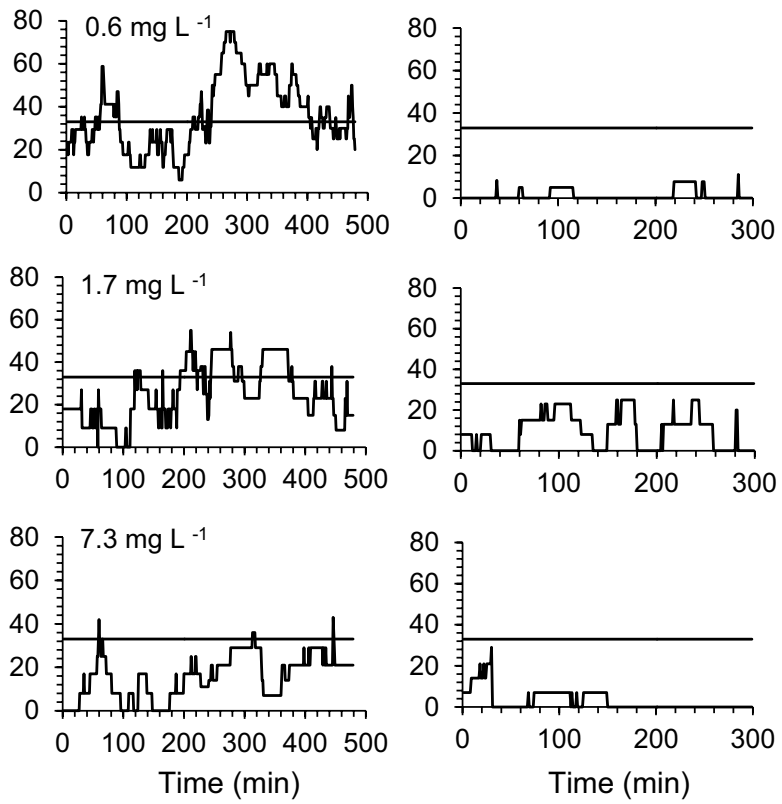

mildly hypoxic $\left(1.7 \mathrm{mg}\right.$ DO $\left.\mathrm{L}^{-1}\right)$ conditions in low plateau phase, $\mathbf{c}$ normoxic $\left(7.3 \mathrm{mg} \mathrm{DO} \mathrm{L}^{-1}\right)$ conditions during low plateau phase in Figs. 1 and 7

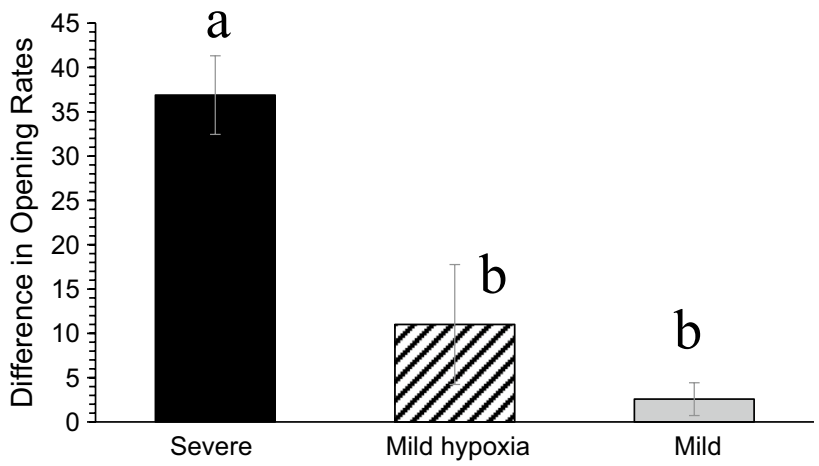

Fig. 9 Mean difference $( \pm$ SE) in time closed (\%) (low plateau minus normoxia after low plateau). Severe hypoxia $=0.6 \mathrm{mg} \mathrm{DO} \mathrm{L} \mathrm{L}^{-1}$ $(n=8)$, mildly hypoxic $=1.7 \mathrm{mg} \mathrm{DO} \mathrm{L}^{-1}(n=4)$, control $=7.3 \mathrm{mg} \mathrm{DO} \mathrm{L}^{-1}(n=4)$. Different letters indicate significant differences (nested ANOVA, $P \leq 0.05$ ). Data for severely hypoxic and control $\mathrm{pH}(\mathrm{pH}=7.8)$ and severely hypoxic and cyclical $\mathrm{pH}$ $(\mathrm{pH}=7.8-7.0)$ were pooled (see text)

(2012), however, found that naturally fed oysters were open $69-80 \%$ of the time, and studies of unfed oysters have reported oysters opening between 35 and $71 \%$ of the time (Galtsoff 1928; Brown 1954; Higgins 1980). Oysters in our control treatment were also open for long periods of time, closing only occasionally, with high variability among individuals. The high individual variability was previously 
observed by Higgins (1980). In all treatments, there was variability between individuals.

The principle of group closure, where, if more than a certain percentage of bivalves closes, an alarm is sounded, has been used in early warning systems (Gnyubkin 2009) such as the Mosselmonitor ${ }^{\circledR}$ (de Zwart et al. 1995) or the Dreissena-Monitor (Borcherding 2006) to detect adverse responses of mussels to pollutants; we found that a larger group of oysters closed under severe hypoxia than mild hypoxia or control conditions (Fig. 8). These results suggest that studies that examine bivalve gape in the environment as a way of monitoring pollutants should also consider DO in areas where hypoxia is possible.

Diel-cycling hypoxia often occurs during the late night/ early morning hours in the summer (Tyler et al. 2009; Breitburg et al. 2015). Patterns of late night bivalve closures have also been observed previously although were not related to potential hypoxia and DO was not measured. Using valve gape measurements over 2 years, Ortmann and Grieshaber (2003) reported that Corbicula fluminea exhibited a circadian rhythm in summer in the Rhine River with extended periods of valve closure, predominantly in the late night hours. However, this pattern did not continue when they brought the bivalves into the laboratory. They explain this pattern as exploitation of the scarce food supply but did not measure potential hypoxia. Comeau et al. (2012) found a diurnal rhythm in the valve openness of $C$. virginica; whereby, openness was greatest near the end of the afternoon and least in the early morning; however, they did not measure [DO] and relate this to light. While DO has not been the focus in many valve gape studies, some bivalve responses may have been due to hypoxia and not the target variable. Our results suggest that DO should also be measured during valve gape experiments at locations where hypoxia is possible.

Previous valve gape studies also have not examined bivalve behavior after a hypoxic event is finished within a diel cycle. In our experiments, oysters closed repeatedly during hypoxic phases but opened again before normoxia was reestablished, and closed only occasionally during high DO phases of the diel cycle between hypoxic events. This behavior was especially pronounced in the severe dielcycling hypoxia treatment (Fig. 5). The percent of time closed during normoxia after severe hypoxia was similar to the control treatment. This is similar to findings based on filtration rates of 1-year-old oysters, and different than the responses of older oysters in which compensatory filtration has been reported following exposure to severe hypoxia (Clark 2014; Breitburg et al. 2015). Small differences in valve gape may have been difficult to detect with the small number of individuals used for these valve gape measurements. Also, while gape has been related to filtration in non-siphonate bivalves (Jørgensen et al. 1988; Riisgård and
Larsen 2015), the two are not synonymous (Cranford et al. 2011) and differential pumping rates (Loosanoff 1962) can contribute to differences in filtration rates.

We found a dramatic difference among treatments in opening rates when shifting from severe hypoxia to normoxia, compared to shifting from mild hypoxia to normoxia. This rapid change in behavior may be adaptive in highly fluctuating conditions in nature to compensate for adverse conditions. Other invertebrates such as the blue crab, Callinectes sapidus, similarly respond quickly to [DO] fluctuations, and the feeding rate of $C$. sapidus exposed to a fluctuating diurnal pattern of hypoxia was significantly higher than that of blue crabs exposed to constant 100 or $16 \%$ saturation (Burnett and Stickle 2001).

Other studies have examined oyster mitochondrial responses to large fluctuations in DO. For example, mitochondria in C. virginica exposed to $<0.5 \%$ DO for 6 days and then reoxygenated were essentially unchanged (Ivanina et al. 2012) and thus adjusted quickly to changing concentrations of DO. In addition, Sussarellu et al. (2013) found rapid mitochondrial adjustments in response to short-term hypoxia and reoxygenation in $C$. gigas. Thus, oysters not only adjust their mitochondrial responses to large fluctuations of DO (Ivanina et al. 2012; Sussarellu et al. 2013) but also adjust gape as found in this study.

While Riedel et al. (2014) found that macroinvertebrate behavior was related to community structure and the ecosystem, ecological disturbance or changes may be prevented by such rapid response behavior and promote ecosystem resilience in response to diel-cycling hypoxia. Scapini (2014) suggested that behavior as an immediate response to environmental change may have a major role in permitting ecosystem resilience under stressful conditions. Moreover, oysters may have adapted in their behavior to the increased occurrence of diel-cycling hypoxia in estuaries as behavioral adaptations contribute to ecosystem response to change (Scapini 2014).

In the mildly hypoxic treatment, valve closure was delayed which indicates that while oysters closed rapidly under severe hypoxia, they often did not close until they had been exposed for several hours to mild hypoxia. The adjustments animals make to deal with environmental fluctuations can result in various lag times (Huey and Bennett 1990). The lag we observed would not have been detected in typical short-term constant hypoxic exposure experiments. Also, if the mildly hypoxic conditions had persisted for a longer time than in this study, it may have affected the oysters more strongly. Oysters that closed in the mild hypoxia treatment opened rapidly when [DO] increased.

Closed gape has been associated with lowered metabolism and lowered oxygen consumption in Mytilus edulis and Corbicula fluminea (Famme 1980; Ortmann and Grieshaber 2003) and initial higher heart rates in Arctica 
islandica and Mytilus edulis (Taylor 1976; Rovero et al. 1999; but see Curtis et al. 2000). These responses were not measured in the present study. Riisgård and Larsen (2015) suggested that the low rate of oxygen consumption in mussels with reduced gape was a consequence of decreasing water flow through the mantle cavity. Ortmann and Grieshaber (2003) calculated that $C$. fluminea remained aerobic for approximately 4-9 h after valve closure in anoxic water, depending on the size of the individual. If this is also true for $C$. virginica, short-term fluctuations with dielcycling hypoxia $(4 \mathrm{~h})$ should render $C$. virginica aerobic throughout its duration. In our study, $C$. virginica opened their valves as soon as normoxic water was reintroduced after the severe hypoxic event. Perhaps, being aerobic made the fast opening of the valves possible.

While our findings apply to 1-year-old $C$. virginica, gape patterns may be different for different bivalve age classes or species. For example, Clark (2014) and Breitburg et al. (2015) found compensatory filtration rates in 3-year-old oysters, but not on 1-year olds. Lombardi et al. (2013) found different responses of C. virginica and C. ariakensis to hypoxia. Thus, this study should be expanded to other age classes of C. virginica and other bivalve species. Moreover, we used oysters fed at libitum. In future studies, the interactive effect of hypoxia and low food concentrations on gape should be examined as these conditions may co-occur in nature.

In ecosystems, animals are exposed to temporally varying conditions such as diel-cycling hypoxia and may exhibit adaptive responses such as the changing valve gape behavior of $C$. virginica found here. Such rapid response behavior may reduce adverse effects both to the oysters themselves and to the ecosystem services they provide. Future studies should include the effects of diel-cycling hypoxia on valve gape behaviors of different bivalve species. Moreover, in situ monitoring of valve gape should include measurements of [DO] to determine whether valves are closed due to responses to hypoxia.

Acknowledgments We thank Andrew Keppel, Virginia Clark, and Rebecca Burrell for maintaining the diel cycling hypoxia conditions throughout this experiment. We thank F. Scott Porter who built the valve gape apparatus. Oysters were purchased from Marinetics, Cambridge, Maryland. The hypoxia experiments were funded by a National Oceanic and Atmospheric Administration - Center for Sponsored Coastal Ocean Research grant No. NA10NOS4780138 and by the Smithsonian Hunterdon Fund to Denise Breitburg. The valve gape measurements during the hypoxia experiments were funded by a Faculty Enhancement Grant by Washington College to Elka T. Porter. We would also like to thank three anonymous reviewers for valuable suggestions that improved the manuscript.

\section{Compliance with ethical standards}

Conflict of interest Author Elka T. Porter declares that she has no conflict of interest. Author Denise L. Breitburg declares that she has no conflict of interest.
Ethical approval All applicable international, national, and/or institutional guidelines for the care and use of animals were followed. This article does not contain any studies with human participants performed by any of the authors.

\section{References}

Altieri AH, Gedan KB (2015) Climate change and dead zones. Glob Change Biol 21:1395-1406. doi:10.1111/gcb.12754

Basti L, Nagai K, Shimasaki Y, Oshima Y, Honjo T, Segawa S (2009) Effects of the toxic dinoflagellate Heterocapsa circularisquama on the valve movement behaviour of the Manila clam Ruditapes philippinarum. Aquaculture 291:41-47. doi:10.1016/j. aquaculture.2009.02.029

Baumann H, Wallace RB, Tagliaferri T, Gobler CJ (2015) Large natural $\mathrm{pH}, \mathrm{CO}_{2}$ and $\mathrm{O}_{2}$ fluctuations in a temperate tidal salt marsh on diel, seasonal, and interannual time scales. Estuaries Coast 38:220-231. doi:10.1007/s12237-014-9800-y

Borcherding J (2006) Ten years of practical experience with the Dreissena-monitor, a biological early warning system for continuous water quality monitoring. Hydrobiologia 556:417-426. doi:10.1007/s10750-005-1203-4

Breitburg DL (1990) Near-shore hypoxia in the Chesapeake Bay: patterns and relationships among physical factors. Estaur Coast Shelf Sci 30:593-609

Breitburg D (2002) Effects of hypoxia, and the balance between hypoxia and enrichment on coastal fishes and fisheries. Estuaries 25:767-781

Breitburg DL, Hondorp D, Audemard C, Carnegie RB, Burrell RB, Trice M, Clark V (2015) Landscape-level variation in disease susceptibility related to shallow-water hypoxia. PLoS One 10:e0116223. doi:10.1371/journal.pone.0116223

Brown F (1954) Persistent activity rhythms in the oyster. Am J Physiol 178:510-514

Burnett LE, Stickle WB (2001) Physiological responses to hypoxia. In: Rabelais NN, Turner RE (eds) Coastal hypoxia: consequences for living resources and ecosystems. coastal and Estuarine Studies 58. American Geophysical Union, Washington, DC, pp 101-114

Burrell RB, Keppel AG, Clark VM, Breitburg DL (2015) An automated monitoring and control system for flow-through cocycling hypoxia and $\mathrm{pH}$ experiments. Limnol Oceanogr Methods. doi:10.1002/lom3.10077

Clark V (2014) The effects of diel-cycling hypoxia and hypercapnia on eastern oyster, Crassostrea virginica (Gmelin), clearance rates and hemolymph $\mathrm{pH}$. University of Maryland, College Park, Master of Science

Comeau LA, Mayrand E, Mallet A (2012) Winter quiescence and spring awakening of the Eastern oyster Crassostrea virginica at its northernmost distribution limit. Mar Biol 159:2269-2279. doi:10.1007/s00227-012-2012-8

Costantini M, Ludsin SA, Mason DM, Zhang X, Boicourt WC, Brandt SB (2008) Effect of hypoxia on habitat quality of striped bass (Morone saxatilis) in Chesapeake Bay. Can J Fish Aquat Sci 65:989-1002. doi:10.1139/f08-021

Cranford PJ, Evans DA, Shumway SE (2011) Bivalve filter feeding: variability and limits of the aquaculture biofilter. In: Shumway $S$ (ed) Shellfish aquaculture and the environment. Wiley, Oxford, pp 81-124

Curtis TM, Williamson R, Depledge MH (2000) Simultaneous, long term monitoring of valve and cardiac activity in the blue mussel Mytilus edulis exposed to copper. Mar Biol 136:837-846

Dame RF, Patten BC (1981) Analysis of energy flows in an intertidal oyster reef. Mar Ecol Prog Ser 5:115-124 
de Zwart D, Kramer JM, Jenner HA (1995) Practical experiences with the biological early warning system "mosselmonitor". Environ Toxicol Water 10:237-247

Dharmamaraj S (1983) Oxygen consumption in Pearl oyster Pinctada fucata (Gould) and Pinctada sugillata (Reeve). Proc Symp Coast Aquac 2:627-632

Diaz RJ, Rosenberg R (1995) Marine benthic hypoxia: a review of its ecological effects and the behavioural responses of benthic macrofauna. Oceanogr Mar Biol Ann Rev 33:245-303

Diaz RJ, Rosenberg R (2008) Spreading dead zones and consequences for marine ecosystems. Science 321:926-929

Dowd WW, Somero GN (2013) Behavior and survival of Mytilus congeners following episodes of elevated body temperature in air and seawater. J Exp Biol 216:502-514. doi:10.1242/jeb.076620

Famme P (1980) Effect of shell valve closure by the mussel Mytilus edulis $\mathrm{L}$. on the rate of oxygen consumption in declining oxygen tension. Comp Biochem Physiol 67a:167-170

Galtsoff PS (1928) Experimental study of the function of the oyster gills and its bearing on the problems of oyster culture and sanitary control of the oyster industry. Bull US Bur Fish 44:1-39

Gamenick I, Jahn A, Vopel K, Giere O (1996) Hypoxia and sulphide as structuring factors in a macrozoobenthic community on the Baltic Sea shore: colonization studies and tolerance experiments. Mar Ecol Prog Ser 144:73-85

Gnyubkin VF (2009) An early warning system for aquatic environment state monitoring based on an analysis of mussel valve movements. Russ J Mar Biol 35:431-436

Gooday AJ, Levin LA, Aranda da Silva A, Bett BJ, Cowie GL, Dissard D, Gage JD, Hughes DJ, Jeffreys R, Lamont PA, Larkin KE, Murty SJ, Schumacher S, Whitcraft C, Woulds C (2009) Faunal responses to oxygen gradients on the Pakistan margin: a comparison of foraminiferans, macrofauna and megafauna. Deep Sea Res Part II 56:488-502. doi:10.1016/j.dsr2.2008.10.003

Higgins PJ (1980) Effects of food availability on the valve movements and feeding behavior of juvenile Crassostrea virginica (Gmelin). I. Valve movements and periodic activity. J Exp Mar Biol Ecol 45:229-244

Huey RB, Bennett AF (1990) Physiological adjustments to fluctuating thermal environments: an ecological and evolutionary perspective. In: Morimoto R, Tissieres A, Georgopoulous C (eds) The role of heat shock and stress response in biology and human disease. Cold Harbor Laboratory Press, New York, pp 37-59

Ivanina AV, Kurochkin IO, Leamy L, Sokolova IM (2012) Effects of temperature and cadmium exposure on the mitochondria of oysters (Crassostrea virginica) exposed to hypoxia and subsequent reoxygenation. J Exp Biol 215:3142-3154. doi:10.1242/ jeb.071357

Jakubowska M, Normant M (2015) Metabolic rate and activity of blue mussel Mytilus edulis trossulus under short-term exposure to carbon dioxide-induced water acidification and oxygen deficiency. Mar Freshw Behav Physiol 48:25-39. doi:10.1080/1023 6244.2014.986865

Jakubowska M, Normant-Saremba $\mathrm{M}$ (2015) The effect of $\mathrm{CO}_{2}$ induced seawater acidification on the behaviour and metabolic rate of the Baltic clam Macoma balthica. Ann Zool Fenn 52:353-367. doi:10.5735/086.052.0509

Jansson A, Norkko J, Dupont S, Norkko A (2015) Growth and survival in a changing environment: combined effects of moderate hypoxia and low $\mathrm{pH}$ on juvenile bivalve Macoma balthica. J Sea Res 102:41-47. doi:10.1016/j.seares.2015.04.006

Jørgensen CB, Larsen P, Møhlenberg F, Riisgård HU (1988) The bivalve pump: properties and modelling. Mar Ecol Prog Ser 45:205-216

Kádár E, Salánki J, Judaosingh R, Powell JJ, McCrohan CR, White KN (2001) Avoidance responses to aluminum in the freshwater bivalve Anodonta cygnea. Aquat Toxicol 55:137-148
Keppel AG, Breitburg DL, Wikfors GH, Burrell RB, Clark VM (2015) Effects of co-varying diel-cycling hypoxia and $\mathrm{pH}$ on disease susceptibility in the eastern oyster Crassostrea virginica. Mar Ecol Prog Ser 538:169-183. doi:10.3354/meps11479

Levin LA, Breitburg DL (2015) Linking coasts and seas to address ocean deoxygenation. Nat Clim Change 5:401-403. doi:10.1038/ nclimate 2595

Llansó RJ (1992) Effects of hypoxia on estuarine benthos: the lower Rappahannock River (Chesapeake Bay), a case study. Estuar Coast Shelf Sci 35:491-515

Lombardi SA, Harlan NP, Paynter KT (2013) Survival, acid-base balance, and gaping responses of the Asian Oyster Crassostrea ariakensis and the Eastern Oyster Crassostrea virginica during clamped emersion and hypoxic immersion. J Shellfish Res 32:409-415. doi:10.2983/035.032.0221

Loosanoff VL (1962) Effects of turbidity on some larval and adult bivalves. In: Proceedings of the Fourteenth Gulf and Caribbean Fisheries Institute, Coral Gables, Florida USA, vol 14, pp 80-94

Loosanoff VS, Nomejko CA (1946) Feeding of oysters in relation to tidal stages and to periods of light and darkness. Biol Bull (Woods Hole) 90:244-264

Ludsin SA, Zhang X, Brandt SB, Roman MR, Boicourt WC, Mason DM, Costantini M (2009) Hypoxia-avoidance by planktivorous fish in Chesapeake Bay: implications for food web interactions and fish recruitment. J Exp Mar Biol Ecol 381:S121-S131. doi:10.1016/j.jembe.2009.07.016

Modig H, Olafsson E (1998) Responses of Baltic benthic invertebrates to hypoxic events. J Exp Mar Biol Ecol 229:133-148

Montagna PA, Ritter C (2006) Direct and indirect effects of hypoxia on benthos in Corpus Christi Bay, Texas, U.S.A. J Exp Mar Biol Ecol 330:119-131. doi:10.1016/j.jembe.2005.12.021

Nicastro KR, Zardi GI, McQuaid CD, Stephens L, Radloff S, Blatch GL (2010) The role of gaping behaviour in habitat partitioning between coexisting intertidal mussels. BMC Ecol 10:17. doi:10.1186/1472-6785-10-17

Nicastro KR, Zardi GI, McQuaid CD, Pearson GA, Serrao EA (2012) Love thy neighbour: group properties of gaping behaviour in mussel aggregations. PLoS One 7(10):e47382

Ortmann C, Grieshaber MK (2003) Energy metabolism and valve closure behaviour in the Asian clam Corbicula fluminea. J Exp Biol 206:4167-4178. doi:10.1242/jeb.00656

Patterson HK, Boettcher A, Carmichael RH (2014) Biomarkers of dissolved oxygen stress in oysters: a tool for restoration and management efforts. PLoS One 9(8):e104440

Pynönnen KS, Huebner J (1995) Effects of episodic low pH exposure on the valve movements of the freshwater bivalve Anodonta cygnea L. Water Res 29:2579-2582

Riedel B, Zuschin M, Haselmair A, Stachowitsch M (2008) Oxygen depletion under glass: behavioural responses of benthic macrofauna to induced anoxia in the Northern Adriatic. J Exp Mar Biol Ecol 367:17-27. doi:10.1016/j.jembe.2008.08.007

Riedel B, Zuschin M, Stachowitsch M (2012) Tolerance of benthic macrofauna to hypoxia and anoxia in shallow coastal seas: a realistic scenario. Mar Ecol Prog Ser 458:39-52. doi:10.3354/ meps09724

Riedel B, Pados T, Pretterebner K, Schiemer L, Steckbauer A, Haselmair A, Zuschin M, Stachowitsch M (2014) Effect of hypoxia and anoxia on invertebrate behaviour: ecological perspectives from species to community level. Biogeosciences 11:1491-1518. doi:10.5194/bg-11-1491-2014

Riisgård HU, Larsen PS (2015) Physiologically regulated valveclosure makes mussels long-term starvation survivors: test of hypothesis. J Molluscan Stud 81:303-307. doi:10.1093/mollus/ eyu087

Riisgård HU, Lassen J, Kittner C (2006) Valve-gape response times in mussels (Mytilus edulis)-Effects of laboratory preceding-feeding 
conditions and in situ tidally induced variation in phytoplankton biomass. J Shellfish Res 25:901-911

Robson AA, De Leaniz CG, Wilson RP, Halsey LG (2010a) Behavioural adaptations of mussels to varying levels of food availability and predation risk. J Molluscan Stud 76:348-353. doi:10.1093/mollus/eyq025

Robson AA, de Leaniz CG, Wilson RP, Halsey LG (2010b) Effect of anthropogenic feeding regimes on activity rhythms of laboratory mussels exposed to natural light. Hydrobiologia 655:197-204. doi:10.1007/s10750-010-0449-7

Rodland DL, Schoene BR, Baier S, Zhang Z, Dreyer W, Page NA (2009) Changes in gape frequency, siphon activity and thermal response in the freshwater bivalves Anodonta cygnea and Margaritifera falcata. J Molluscan Stud 75:51-57. doi:10.1093/ mollus/eyn038

Rovero F, Hughes RN, Chelazzi G (1999) Cardiac and behavioural responses of mussels to risk of predation by dogwhelks. Anim Behav 58:707-714

Scapini F (2014) Behaviour of mobile macrofauna is a key factor in beach ecology as response to rapid environmental changes. Estuar Coast Shelf Sci 150:36-44. doi:10.1016/j. ecss.2013.11.001

Shumway SE, Cucci TL (1987) The effects of the toxic dinoflagellate Protogonyaulax tamarensis on the feeding and behaviour of bivalve molluscs. Aquat Toxicol 10:9-27

Shumway SE, Koehn RK (1982) Oxygen consumption in the American oyster Crassostrea virginica. Mar Ecol Prog Ser 9:59-68

Soliman MFM, El-Shenawy NS, Tadros MM, Abd El-Azeez AA (2015) Impaired behavior and changes in some biochemical markers of bivalve (Ruditapes decussatus) due to zinc toxicity. Toxicol Environ Chem 97:674-686. doi:10.1080/02772248.201 5.1058381
Sparks BL, Strayer DL (1998) Effects of low dissolved oxygen on juvenile Elliptio complanata (Bivalvia:Unionidae). J N Am Benthol Soc 17:129-134

Stickle WB, Kapper MA, Liu L-L, Gnaiger E, Wang SY (1989) Metabolic adaptations of several species of crustaceans and molluscs to hypoxia: tolerance and microcalometric studies. Biol Bull (Woods Hole) 177:303-312

Sussarellu R, Dudognon T, Fabioux C, Soudant P, Moraga D, Kraffe E (2013) Rapid mitochondrial adjustments in response to shortterm hypoxia and re-oxygenation in the Pacific oyster, Crassostrea gigas. J Exp Biol 216:1561-1569. doi:10.1242/jeb.075879

Taylor AC (1976) The cardiac responses to shell opening and closure in the bivalve Arctica islandica (L.). J Exp Biol 64:751-759

Tran D, Haberkorn H, Soudant P, Ciret P, Massabuau J-C (2010) Behavioral responses of Crassostrea gigas exposed to the harmful algae Alexandrium minutum. Aquaculture 298:338-345. doi:10.1016/j.aquaculture.2009.10.030

Tyler RM, Brady DC, Targett TE (2009) Temporal and spatial dynamics of diel-cycling hypoxia in estuarine tributaries. Estuaries Coast 32:123-145. doi:10.1007/s12237-008-9108-x

Vaquer-Sunyer R, Duarte CM (2008) Thresholds of hypoxia for marine biodiversity. Proc Natl Acad Sci U S A 105:1545215457. doi:10.1073/pnas.0803833105

Villnäs A, Norkko J, Lukkari K, Hewitt J, Norkko A (2012) Consequences of increasing hypoxic disturbance on benthic communities and ecosystem functioning. PLoS One 7:e44920. doi:10.1371/journal.pone.0044920

Zhang H, Ludsin SA, Mason DM, Adamack AT, Brandt SB, Zhang X, Kimmel DG, Roman MR, Boicourt WC (2009) Hypoxia-driven changes in the behavior and spatial distribution of pelagic fish and mesozooplankton in the northern Gulf of Mexico. J Exp Mar Biol Ecol 381:S80-S91. doi:10.1016/j.jembe.2009.07.014 


\section{Electronic supplemental material.}

Eastern oyster, Crassostrea virginica, valve gape behavior under diel-cycling hypoxia, Marine Biology,

Elka T. Porter* \& Denise L. Breitburg, *University of Baltimore, *eporter@ubalt.edu

Number of oysters with gape sensors used in the different aquaria for each treatment. For diel-cycling severe hypoxia (0.6 mg DO L-1) two $\mathrm{pH}$ treatments, i.e., control $(\mathrm{pH}=7.8)$ and cyclical $(\mathrm{pH}=7.8-7.0)$, were combined $(\mathrm{n}=24$, see text). Overall sample size in each aquarium was affected by occasional sensor failure as well as equipment limitations in deploying sensors in the facility.

\begin{tabular}{|c|c|c|c|c|}
\hline & $\begin{array}{c}0.6 \text { mg L-1 } \\
\text { cyclical pH } \\
\text { at low } \\
\text { plateau }\end{array}$ & $\begin{array}{c}0.6 \mathrm{mg} \mathrm{L}^{-1} \\
\text { control pH } \\
\text { at low } \\
\text { plateau,b }\end{array}$ & $\begin{array}{c}1.7 \mathrm{mg} \mathrm{L}^{-1} \\
\text { at low } \\
\text { plateau }\end{array}$ & $\begin{array}{l}7.3 \mathrm{mg} \mathrm{L}-1 \\
\text { normoxia }\end{array}$ \\
\hline aquarium 1 & 3 & 3 & 3 & 3 \\
\hline aquarium 2 & 3 & 3 & 4 & 3 \\
\hline aquarium 3 & 3 & 2 & 2 & 3 \\
\hline aquarium 4 & 4 & 3 & 2 & 2 \\
\hline $\begin{array}{l}\text { \# gape } \\
\text { oysters per } \\
\text { treatment }\end{array}$ & 13 & 11 & 11 & 11 \\
\hline
\end{tabular}

a $0.6 \mathrm{mg} \mathrm{DO} \mathrm{L}^{-1}$ cyclical $\mathrm{pH}$ and control $\mathrm{pH}$ treatments were combined $(n=24)$

b 1 additional aquarium with 1 oyster was run but excluded from statistical analysis 